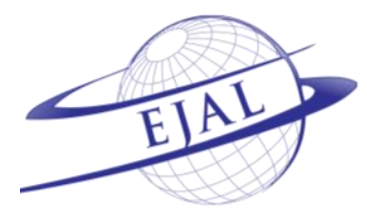

Available online at www.ejal.eu

\title{
Processing Instruction Revisited: Does it Lead to Superior Performance in Interpretation and Production?
}

\author{
Majid Farahian a * (D), Farnaz Avarzamani à \\ a Department of ELT, College of Literature and Humanities, Kermanshah Branch, Islamic Azad University, \\ Kermanshah, Iran
}

Received 19 May 2018 | Received in revised form 29 July 2018 | Accepted 12 October 2018

\begin{abstract}
APA Citation:
Farahian, M., \& Avarzamani, F. (2019). Processing instruction revisited: Does it lead to a superior performance in interpretation and production? Eurasian Journal of Applied Linguistics, 5(1), 89-111. Doi: 10.32601/ejal.543783
\end{abstract}

\begin{abstract}
There have been plenty of research studies which have demonstrated the efficacy of focus on form (FonF) approach in language teaching. However, processing instruction as a kind of FonF approach has not been given due attention. As such, the present study is an attempt to shed more lights upon the effects of the processing instruction (PI) on EFL (English as a Foreign Language) learners' acquisition of passive voice by comparing PI to dictogloss and an output instruction. The participants recruited for the study were 51 pre-intermediate level EFL students. The pretest revealed that there was no significant difference between the groups regarding passive voice knowledge. As to the treatment, the first group $(n=17)$ received processing instruction, the second group $(n=17)$ was exposed to dictogloss tasks, and the third $(n=17)$ was given meaningful output instruction. In the immediate posttest, two types of tasks (interpretation and production) were used to assess the participants' English passive voice comprehension and production. The findings indicated that the processing instruction group outperformed dictogloss and meaningful output instruction in both tasks, and thus it had a significantly positive effect on the comprehension and production of the English passive voice.
\end{abstract}

(C) 2019 EJAL \& the Authors. Published by Eurasian Journal of Applied Linguistics (EJAL). This is an open-access article distributed under the terms and conditions of the Creative Commons Attribution license (CC BY-NC-ND) (http://creativecommons.org/licenses/by-nc-nd/4.0/).

Keywords: processing instruction; dictogloss; meaning-based output instruction; English passive voice

\section{Introduction}

The field of the second language (SL) and foreign language (FL) acquisition pedagogy is witnessing an increasing interest in the idea of FonF and the suggestion that attention to form should be encouraged in L2 classrooms (Doughty \& Williams, 1998; Ellis, 2016). In fact, to focus on form in classrooms is to "overtly draw students' attention to linguistic elements as they arise incidentally in lessons whose overriding focus is on meaning or communication" (Long, 1991, pp. 45-46). The related literature has indicated that FonF improves the L2 acquisition of morpho-syntactic forms (Qin, 2008). While the wind shifted in favor of the focus on form, researchers have sought to

\footnotetext{
* Corresponding author.

E-mail address: farahian@iauksh.ac.ir

†
} 
examine whether there are particular types of focus on form instruction which are more beneficial than others. Among various forms of the FonF instruction, PI, as an input-based instruction, has been compared with output-based approaches such as traditional grammar instruction (TI) (Cadierno, 1995), dictogloss (DG) (Qin, 2008), and meaning-based output instruction (MOI) (Benati, 2005; Farley, 2001, 2004).

As highlighted by Benati (2005), the primary role of input in the L2 acquisition had often been emphasized in VanPatten's works (e.g. VanPatten, 1996) and a less fundamental role has been assigned to output. Although VanPatten (1996) highlights the fundamental role of input, for him, mere exposure to input does not guarantee to learn (Sheen, 2007). As VanPatten (1996) suggested, learners may use inefficient strategies to process input; therefore, they should be trained on how to process input properly in order to better acquire grammar forms. This type of teaching is known as processing strategy (VanPatten, 1996). It is important to disentangle PI from input processing (IP). As Sheen (2007) explains, while IP is related to VanPatten's (1996) theoretical model and assumption about what goes on in the brain when perceiving the input, PI refers to the things that instructors do to bring the grammar of the input to learners' notice. He argues that explicit types of instruction like PI help learners process information via comprehension practice and might be more effective than the ones which require learners to produce language too prematurely. In this regard, some studies (Cadierno, 1995) have compared PI to TI which provides an explanation of L2 forms accompanied by some type of practice such as mechanical, meaningful, and communicative output-based practices (VanPatten, 2004a). Because of the nature of TI which is based on mechanical drills and repetition, it is not discussed in the present study, and it is replaced by another output-based instruction, namely, meaning-based output instruction (MOI). Unlike TI, the activities in MOI are based on the tenets of structured-output activities and no mechanical drills are used in MOI instruction and it includes only output based activities (Lee \& VanPatten, 1995). Therefore, this meaningful type of instruction was considered to address the shortcoming.

The other choice for explicit grammar instruction is Dictogloss (DG). DG consists of four stages: preparation, dictation, reconstruction, and analysis with correction (Wajnryb, 1990). Dictogloss tasks require learners to focus their attention on form as they reconstruct the text. Besides, DG allows learners to engage in meaningful negotiation and at the same time, they attend to linguistic forms. This is based on the idea of noticing (Schmidt, 1990) and noticing-the-gap process (Shack, 2004) since dictogloss overtly diverts learners' attention to the differences between their interlanguage and the target language. It is noteworthy that Qin (2008) prefers DG to MOI and mentions different advantages for it. Firstly, as he claims, it addresses teaching language in discourse and emphasizes the whole language view. Secondly, much research has shown that similar to PI, DG may result in attention to language form in meaningful contexts. These, as maintained by Qin (2008), can help learners to be exposed to the L2 and, at the same time, reconstruct the language for themselves. 
Although the benefits of PI have been highlighted many times, results are yet to be conclusive. For example, the findings of studies conducted by Qin (2008) and VanPatten, Inclezan, Salazar and Farley (2009) were not consistent. Qin (2008), who compared PI to DG found that both groups showed significant improvement in the posttest, while in VanPatten et al. (2009), the researchers reported that PI was notably superior to the DG group. In addition to the previous comparisons between PI and DG instructions in the literature, the present study differs in that it included MOI so as to examine PI efficacy more closely against meaning-based and outputoriented types of grammar instruction on the sentence level (see Table 3). Furthermore, different participants were recruited since Qin's (2008) study was conducted at schools where the learners' motivation may not be as high as the learners who have voluntarily attended language institutes. Therefore, school learning may not represent the real condition in which L2 learners interact to learn the language (Ellis, 2003).

The present study intended to reveal possible strength of PI instruction for grammar and for this purpose the English passive voice was chosen due to some legitimate reasons. This grammatical feature, especially for Iranian students, poses problems both in comprehension and production, and thus it is considered to be a difficult grammar feature by learners and teachers (Vahedi-Langrudi, 1996). Consequently, it seemed worthwhile to see if FonF instruction was efficient enough in the acquisition of this grammatical feature. Another major reason for choosing the passive voice for the present study was one of the principles (First Noun Principle) in VanPatten's model (2005) which suggests that L2 learners adopt ineffective processing strategies while learning and, in the case of passive voice, they may tend to process the first noun as the agent in all cases. Having this (and the aforementioned research gap) in mind, we aimed to see whether PI is a superior type of grammar instruction in our context. In the following section, the background of the present study and the previous research are presented in more details.

\section{Review of literature}

Over the past couple of decades, there have been a number of thorough reviews which have revealed the vital importance of focusing on form and its facilitative role in SL and FL learning (Ellis, 2002; Ellis, 2016; Norris \& Ortega, 2000). Apart from advocating the FonF method of teaching, there has been a debate regarding the impact of it on the target language learning. Ellis (1994) proposed a hypothesis, called 'Selective Attention'. This hypothesis claims that formal instruction acts as a facilitator of acquisition and prepares learners for acquiring the input. As Ellis (1994) asserts, "instruction works by helping learners to pay selective attention to form and form-meaning connections in the input. It provides learners with tools that help them recognize those features in their interlanguages which are in need of modification" ( $p$. 656). Ellis (1994) considers the Selective Attention Hypothesis as the most 'tenable' hypothesis concerning the role of instruction. In the same vein, Sharwood-Smith (1993) who coined the term 'input enhancement' suggested that through an external 
attempt some features of the input can be more noticeable to the learners. This is in keeping up with the tenets of PI (VanPatten, 1996).

\subsection{Theoretical background}

PI provides opportunities for learners to attend to form even though it does not consider this to be sufficient for acquisition to take place (VanPatten, 1996). Such emphasis on attention has not been without critics (Iwanaka, 2007). Some argue that the way attention has been dealt with has gone beyond bringing forms into learners' attention. They state that PI can be more of focus on forms (FonFs) since there is a nonspontaneous explicit expression of form in such instruction (Sheen, 2007). In contrast, there are others who consider it as a type of focus on form instruction and claim that PI "does not prescribe any role for explicit knowledge...processing instruction is concerned with delivering form meaning connections as intake to the developing system" (VanPatten, 1996, p. 85). In addition, PI is not "sacrificing either communication or learner centered activities" (Lee \& VanPatten, 1995, p. 94). As the latter group believes, although there is an explicit instruction of grammar in PI, learners' attention is drawn to form in a meaningful context.

In this regard, VanPatten (2004a) explains that input processing refers to the learners' initial attempts to connect grammatical forms with their meanings. As he states, the input alone may not be sufficient for language acquisition and there is a need for the input to be structured and purposeful. According to Lew (2008), the PI attempts to respond to the question "how can input processing be manipulated to fuel the development of an implicit linguistic system?" (p. 2). Therefore, it is thought to be more effective as it provides a more direct route to convert the input to intake because it helps learners to recognize target grammatical features more efficiently without any pressure from the teacher to immediately use the target form. One should be cautious when considering the role of PI in the acquisition of grammar points since, as Sheen (2007) argues, it is not easy for learners to get the input and recognize the structure in it. What is needed to help them effectively process the underlying grammar form is frequent practices. According to Benati (2005), in VanPatten's model, PI must provide learners with the following: 1) explicit information about the target form that they are learning and particular processing strategy that may affect the way they process the target form during comprehension. 2) The teacher should also provide the type of comprehension practice (structured input activities) that leads learners to process the target form in the input and to make form-meaning connections. VanPatten (2004b) did not agree with the claim that "using a form in one's output is a direct path to acquisition" (p. 27) and rejected the idea that acquisition depends on the output (VanPatten, 2004a).

It should be stated that there are at least two perspectives that assume a more fundamental role for output in SLA (Second Language Acquisition). One perspective has suggested that both input and output develop corresponding comprehension and production skills (DeKeyser, 1997, 2001). The second point of view, namely the output 
hypothesis (Swain, 1998), holds that although input is essential to SLA, it can also bring about mental processes that affect language acquisition. Research motivated by this hypothesis has supported a positive role for output practice in conjunction with input (Izumi, 2002). On the other hand, VanPatten and Cadierno (1993, p. 240) showed that "instruction is apparently more beneficial when it is directed at how learners perceive and process input rather than when it is focused on practice via output." Although the researchers did not reject the role of output activities in instruction for developing fluent and accurate production, they claimed that output practice cannot change the nature of interlanguage (VanPatten \& Cadierno, 1993, p. 46). Unlike TI which puts emphasis on the output, PI attempts to change the way learners process the received input, and thus it has an effect on L2 learners' underlying developing system which, in turn, may have an effect on their output. As VanPatten $(1996,2000)$ claims, this effect may not be achieved by any type of outputbased instruction.

Interestingly, recent studies advocate the critical role of the output tasks provided that they serve a purpose. As a clarification, in a recent paper by Benati (2017), the role of structured output tasks was highlighted as he stated "structured output tasks should follow structured input tasks to ensure learners develop the abilities to interpret and produce sentences and discourse containing a target linguistic feature" (p. 391). Furthermore, in a recent meta-analysis by Shintani, Li, and Ellis (2013), they found that both production-based and comprehension-based grammar instructions are advantageous "for both receptive and productive knowledge" (pp. 322323). The point here is that the way and the situation in which teachers use either input or output tasks is crucial. In this regard, current studies (Ellis \& He, 1999; Mackey, 1999; Swain, 2000) are mostly dealing with the appropriate occasions in which either of the above-mentioned task types should be employed, rather than the superiority of any of the instruction or task types in general.

All in all, a debate has been ongoing on whether PI is a better alternative for TI. In this regard, citing the work of DeKeyser and Sokalski, Qin (2008) argues that the differences in the interactional effect may have been due to the mechanical drills. In response to such reaction, some studies compared PI to MOI; however, the results were not conclusive and were, in some cases, contradictory. For instance, as Benati (2005) reported, compared to MOI, PI results in learners' superior comprehension of target forms; however, both have a similar effect on learners' production of target forms. This was in line with an earlier study by Farley (2001). However, in a further study, it was shown that PI and MOI had the same effect on learners' comprehension and production of L2 forms (Farley, 2004). In another study by Qin (2008), it was demonstrated that in the delayed posttest, the DG which is an output-based instruction had the same effect as the PI group on learners' grammar acquisition and this was revealed in both the interpretation and production tasks. However, as he demonstrated, the PI group outperformed the DG in the immediate posttest. Since the effectiveness of dictogloss has been investigated by different research studies (Shack, 2004) a number of reasons have been proposed to encourage the use of dictogloss such 
as its attention to both form and meaning and also its underlying discourse-oriented approach to language (Qin, 2008). Moreover, while learners reconstruct the text in a dictogloss task, they produce an output. Notwithstanding, the advantages of DG have not always been supported (Alderson, 1997). As an instance, VanPatten et al. (2009) argued that DG benefits may not remain over time and in their reconstruction measure, they found no advantage for DG. On the other hand, they revealed that PI was beneficial both in short and long-term.

As such, the present study aims to find out whether PI is significantly superior to DG and MOI when dealing with teaching new complicated structures like the English passive voice to pre-intermediate Iranian EFL learners. In general terms, this is an attempt to find out if PI can significantly turn FL input into intake in the acquisition process of unfamiliar target language structures. Accordingly, the present study can contribute to the PI research by seeking answers to the following questions.

1. Does the PI significantly improve EFL learners' comprehension of English passive voice compared to DG and MOI?

2. Does the PI significantly improve EFL learners' production of English passive voice compared to DG and MOI?

\section{Method}

\subsection{Research design}

The design used in this study was quasi-experimental, and a pretest-posttest design was used. Two weeks before the instruction, the pretest was given to the participants. The treatment lasted twelve sessions and each session was one hour and a half. An immediate posttest was carried out to compare the performance of the participants.

\subsection{Participants}

The participants who took part in this study were 51 (ranging in age from 13 to 15) grade 8 pre-intermediate learners studying English as their FL in a language school in Kermanshah, a city in the west of Iran. They were roughly considered as preintermediate based on the exam and interviews conducted by the language school in the previous term. Based on their teacher's report (there was just one teacher involved in the treatment classes), the participants had no prior knowledge of English passive voice.

\subsection{Treatments}

Three types of grammar instructions (PI, DG, \& MOI) were employed as the treatments. The preparation and organization of the processing instruction materials, dictogloss tasks, and testing materials were adapted from Qin (2008), and the meaningful output activities were developed by the authors. It should be noted that since teachers had little information regarding processing instruction, the necessary 
information was given to them at the office of the language department by the authors in two sessions. To do so, the researchers exemplified each step the teachers required to take and also the necessary strategies they might need. It should be noted that the researchers were cautious not to give a further explanation regarding the tenets of form-focused instruction and not to favor one instructional method.

\subsubsection{Processing instruction materials}

Based on the guidelines presented in Wong (2004) and Qin (2008), the PI materials were presented in the following way. First, the passive voice and its structure were explicitly introduced to the participants. Next, the participants were made aware of some helpful processing strategies in order to remember the first noun as the subject of the sentence without enough attention to the rest of the structure.

Two different types of structured input activities were used in the study: referential and affective. In the former, students were required to attend to the forms in order to get their meanings, and in the latter, the learners were required to express their own personal ideas and opinions. As the final step, structured input activities were presented during the treatment sessions to the subjects. Table 1 presents the order and type of activities in brief.

Table 1. Activities and their features in Processing Instruction

\begin{tabular}{|c|c|c|c|}
\hline Processing Instruction Tasks & Type & Level & Purpose \\
\hline $\begin{array}{l}\text { 1. The students pair each drawing with a sentence from } 12 \\
\text { available sentences ( } 6 \text { active and } 6 \text { passive voice). }\end{array}$ & Referential & Sentence & Form-meaning connection \\
\hline $\begin{array}{l}\text { 2. The students choose the correct form of the verb for each } \\
\text { sentence in a story context. }\end{array}$ & Referential & Discourse & Form-meaning connection \\
\hline 3. The students answer the questions based on a story. & Referential & Discourse & Form-meaning connection \\
\hline $\begin{array}{l}\text { 4. The students respond to a series of statements by the } \\
\text { teacher and with Yes or No. }\end{array}$ & Affective & Sentence & $\begin{array}{l}\text { Reinforcement of Form- } \\
\text { meaning connection by the past } \\
\text { personal observations }\end{array}$ \\
\hline $\begin{array}{l}\text { 5. The students respond to a series of statements by the } \\
\text { teacher and with Yes or No. }\end{array}$ & Affective & Sentence & $\begin{array}{l}\text { Reinforcement of Form- } \\
\text { meaning connection by the past } \\
\text { personal experiences }\end{array}$ \\
\hline
\end{tabular}

Note that the teacher feedback was available through the activities. The materials of the administered tasks are available in Appendix A.

\subsubsection{Dictogloss tasks material}

Because of the awareness-raising nature of DG tasks, the explicit explanation was provided in this type of treatment. The DG material presented to the participants were fairly the same as PI materials to make sure that the differences in treatment were only because of the treatment. Table 2 provides information about DG stages. In addition, the sample of story passages is presented in Appendix B. 
Table 2. Dictogloss Stages and their Purposes

\begin{tabular}{ll}
\hline Dictogloss Steps & Purpose \\
\hline $\begin{array}{l}\text { 1. The teacher describes the main idea of a story and gives its copies to the } \\
\text { students }\end{array}$ & $\begin{array}{l}\text { Preparation and content } \\
\text { comprehension }\end{array}$ \\
\hline $\begin{array}{l}\text { 2. The teacher asks the students to read the story and attend to both } \\
\text { meaning and form (passive forms). }\end{array}$ & $\begin{array}{l}\text { Comprehension of the meaning and } \\
\text { the agent or patient of sentences }\end{array}$ \\
\hline $\begin{array}{l}\text { 3. The teacher asks the students to work in pairs and recreate the text that } \\
\text { they have just read. }\end{array}$ & $\begin{array}{l}\text { Reconstruction of both meaning and } \\
\text { form (with an emphasis on passive } \\
\text { sentence production) }\end{array}$ \\
\hline $\begin{array}{l}\text { 4. The teacher gives back the copies and asks the students to compare and } \\
\text { contrast their passages with the original one. }\end{array}$ & $\begin{array}{l}\text { Reflection on the reconstructed } \\
\text { passages }\end{array}$ \\
\end{tabular}

\subsubsection{Meaningful output instruction materials}

The way that MOI was presented is based on the study conducted by Benati (2005) (Table 3). The learners in this group were first exposed to the same instructional materials as the other groups. Firstly, there was explicit information about the grammatical features. Later, they received information about strategies, and at last, they were exposed to structured output activities. Therefore, the only difference which caused this type of treatment to be different with that of PI group was that the participants were required to access the particular form or structure in order to express meaning and produce language. As stated by Benati (2017, p. 390), structured output activities have two important features: "They involve the exchange of previously unknown information, and they require learners to access a particular form or structure in order to process meaning."

Table 3. Stages of Meaning-based Output Instruction and their Purposes

\begin{tabular}{ll}
\hline Steps in Meaning-based Output Instruction & Purpose \\
\hline 1. The teacher explicitly teaches the passive voice. & $\begin{array}{l}\text { Provide explicit knowledge as a } \\
\text { preparation }\end{array}$ \\
\hline 2. The teacher equips students with useful strategies. & $\begin{array}{l}\text { Awareness raising for the production } \\
\text { process }\end{array}$ \\
\hline $\begin{array}{l}\text { 3. The teacher engages students in structured and meaningful output- } \\
\text { oriented tasks }\end{array}$ & $\begin{array}{l}\text { Practice target feature via meaningful } \\
\text { activities }\end{array}$ \\
\hline
\end{tabular}

\subsection{Data collection and procedure}

A pretest which was the interpretation task was administered a few weeks before the beginning of the instructional period. It was also used to eliminate subjects from the original pool. Anyone who scored $60 \%$ or above on the assessment measure was not included in the final pool. The test included two types of questions: interpretation and production. 
The first and second task (see Appendix A) included five sentences which required the learners to identify the agent and the patient of the sentences. The third task asked the participants to choose the appropriate answer, keeping in mind that the type of voice they choose is important. As to the fourth task, the participants were asked to choose the sentence with an appropriate voice based on the given situation. All in all, there were 17 items which assessed the participants' comprehension of passive voice.

To test the participants' production, the fifth, the sixth and the seventh tasks (see Appendix A) were employed. The fifth task asked the subjects to translate four simple English sentences into Farsi. There were five sentences in the sixth task and participants were asked to fill in the blanks with suitable voices. In the seventh task, the participants were supposed to read the story and fill in the blanks. Key vocabulary items with clear definitions were written on the board beforehand. The difference between the sixth and the seventh task was that the seventh task was more contextualized and had larger discourse. On the whole, there were 17 items in the production section. Contrary to Qin's (2008) study in which the participants were asked to translate a story to their mother tongue, the translation was not used in this study as a testing tool since the learners were not proficient and experienced enough to do the translation on the discourse level. There was also the concern that their ability to write passive sentences to be affected by their inefficiency to translate the story.

\subsection{Data analysis}

In the comprehension section, each question received one point. The score was zero for incorrect answers. This type of scoring was done in the production section as well. On the whole, these tasks received 17 points. Each item in the sixth task received one point. In the sixth task, the participants were asked to read the sentences and fill in the blanks. There were five verbs in this part, and the learners were required to read the story once to get the main idea, and then fill in the blanks using the appropriate voice.

In order to compare the treatment groups, we employed one-way ANOVA (F-critical $=3.14$ ) and as a post-hoc test, we used the Tukey's HSD test (q critical value = 3.40). All the statistical analyses were conducted via the SPSS (ver. 22) software with a significance level of 0.05 for all the analyses.

\section{Results}

\subsection{Results of the pretest}

The performance of PI, DG, and MOI on the pretest was compared. Based on table 4 , the three groups' means are not notably different. In fact, the EFL learners in the present study were similar in their lack of knowledge of how to discern and use 
English passive voice at the beginning of the study. Table 5 presents the inferential statistics in this regard.

To test the significance of the difference, a one-way ANOVA was performed (Table 5). Since the value of F-observed (.512) is lower than that of F-critical (3.14), it can be concluded that there was no significant difference in terms of the groups' performance on the pretest. Therefore, the three groups were relatively homogeneous before the treatment. Note that since the participants were pre-intermediate EFL learners without any notable knowledge of English passive voice, we merely used the interpretation section of the tasks as the pretest.

Table 4. Mean scores of the groups on the pretest

\begin{tabular}{ccc}
\hline Treatment Groups & Mean & Standard Deviation \\
\hline PI & 7.99 & 3.23 \\
DG & 7.95 & 3.09 \\
MOI & 8.25 & 2.11 \\
\hline
\end{tabular}

Table 5. ANOVA for comparing the performance of the three groups on the pretest

\begin{tabular}{ccccc}
\hline Sources of Variance & $\begin{array}{c}\text { sum of } \\
\text { squares }\end{array}$ & df. & Mean square & F \\
\hline Between Groups & 10.36 & 2 & 4.17 & .512 \\
Within Groups & 478.11 & 63 & 8.123 \\
Total & 489.83 & 65 & & \\
\hline
\end{tabular}

F- critical $=3.14 \quad$ level of probability: $p=0.05$

\subsection{Results of the posttest}

As can be implied in Table 6, the mean of PI is higher than the others. In other words, students who were exposed to the PI treatment did better in comprehending the English passive voice statements and its components. To test the significance of this difference, we conducted ANOVA. Table 7 demonstrates that the value of $\mathrm{F}$ observed (11.74) exceeds that of F-critical (3.14). Thus, there is a meaningful difference between the means of the three treatment groups. The Eta squared effect size (.34) indicates that $34 \%$ of the total variance is accounted for by the effect of PI treatment.

Table 6. Mean scores of the groups on the posttest (interpretation task)

\begin{tabular}{ccc}
\hline Treatment Groups & Mean & Standard Deviation \\
\hline PI & 14.48 & 2.11 \\
DG & 11.12 & 3.11 \\
MOI & 10.90 & 2.51 \\
\hline
\end{tabular}


Table 7. ANOVA for comparing the performance of the three groups on the posttest (interpretation task)

\begin{tabular}{ccccc}
\hline Sources of Variance & $\begin{array}{c}\text { Sum of } \\
\text { Squares }\end{array}$ & df. & Mean Square & F \\
\hline Between Groups & 199.48 & 2 & 100.11 & 11.74 \\
Within Groups & 423.71 & 63 & 6.79 & \\
Total & 583.11 & 65 & & \\
\hline
\end{tabular}

F- critical $=3.14$ level of probability: $p=0.05$

Table 8. Tukey's HSD (interpretation task)

\begin{tabular}{ccc}
\hline Treatments & Tukey's HSD (q) & Cohen's d Effect Size \\
\hline PI \& DG & 9.20 & .33 \\
PI \&MOI & 9.81 & .35 \\
DG \& MOI & 0.60 & \\
\hline
\end{tabular}

The critical values for q corresponding to alpha $=.05$ is 3.40

As a post-hoc test, the Tukey's HSD was conducted to find the area of difference. The test indicated that the effect of instruction was due to the following contrasts: the PI was significantly different from the DG group and the MOI group with almost small effect sizes. There was no difference between the MOI and DG group (Table 8). As can be implied, the difference found between PI and MOI is slightly larger than the one between PI and DG.

Table 9. Mean scores of the groups on the posttest (production task)

\begin{tabular}{ccc}
\hline Treatment Groups & Mean & Standard Deviation \\
\hline PI & 10.10 & 2.48 \\
DG & 8.98 & 2.63 \\
MOI & 8.11 & 3.13 \\
\hline
\end{tabular}

Based on Table 9, the mean of PI is again higher than the others. In fact, the participants in this group outperformed others in the DG and MOI groups in terms of the ability to produce English passive voice statements. Table 10 indicates whether this difference is statistically significant or not. The ANOVA conducted on the posttest shows that there is a meaningful difference between the means of all the three groups. Based on the Tukey's HSD test, the difference was due to the following contrasts: The PI significantly outperformed the DG and MOI groups. The calculated effect sizes are in the range of small effect (Table 11). 
Table 10. ANOVA for comparing the performance of the three groups on the posttest (production task)

\begin{tabular}{ccccc}
\hline Sources of Variance & $\begin{array}{c}\text { Sum of } \\
\text { Squares }\end{array}$ & df. & Mean Square & F \\
\hline Between Groups & 201.12 & 2 & 99.11 & 5.14 \\
Within Groups & 591.73 & 63 & 6.81 & \\
Total & 611.38 & 65 & & \\
\hline
\end{tabular}

F- critical $=3.14 \quad$ level of probability: $p=0.05$

Table 11. Tukey's HSD (production task)

\begin{tabular}{ccc}
\hline Treatments & Tukey's HSD (q) & Cohen's d Effect Size \\
\hline PI \& DG & 3.50 & .11 \\
PI \&MOI & 5.44 & .20 \\
DG \& MOI & 2.38 & \\
\hline
\end{tabular}

The critical values for q corresponding to alpha $=.05$ is 3.40

\section{Discussion}

As to the first question of the study which sought to compare PI to two other types of grammar instruction (DG \& MOI) in terms of their impacts on learners' comprehension of passive voice, the result of the statistical analysis indicated that the participants in the PI treatment group significantly outperformed DG and MOI on the interpretation task. This is in line with the findings on the effects of PI discussed in the review of the literature (VanPatten \& Cadierno, 1993; VanPatten et al., 2009) and also the findings of other researchers (Benati, 2005; Qin, 2008) who reported the positive effect of PI as altering and readjusting learners' default processing strategy. Furthermore, the findings showed that PI can be a useful form-focused activity which helps learners make form-meaning connections in the process of grammar acquisition. The evidence collected here shows that PI may not only be an effective instructional treatment compared to DG but also to MOI. To put it another way, the MOI did not bring about the same results as PI did. Based on the findings, it can also be concluded that although all three groups received the same kind of explicit information, perhaps, the structured input activities which aimed to alter L2 learners' inefficient processing strategies might be responsible for a better performance.

As an answer to the second research question, the findings of the present study support the effectiveness of PI in improving learners' performance in production tasks. It concurred with Williams and Evans' (1998) findings in that DG, which is a sort of awareness-raising instruction, did not help the participants to do well in the posttest study. On the other hand, it is in contrast to Qin's (2008) finding in which DG group improved significantly both in the comprehension section and the written production section. Although the DG group's performance improved in the production tasks, the result was not significant in our study. Perhaps, DG was not responsible for 
changing the underlying language processing of FL learners since, as was proposed by Alderson (1997), DG "may not be so effective with lower level learners" (p. 365).

Regarding output-oriented instructions, VanPatten (2004b) argued that the output may have some effects on the acquisition by making input more manageable and by "moving elements into more salient positions" (p. 27). Notwithstanding, as he argues, the mere output is not responsible for the implicit system. In our study, DG and MOI, as output-based instructions, improved participants' interpretation, and production after the pretest, however, the result was not statistically significant. It should be noted that the PI improved participants' performance on the interpretation tasks much more than their performance on the production tasks (See Tables 7 and 10). Here, a caveat is in order. Although we found that PI was superior to both DG and MOI, this does not mean PI altered the innate processing strategies (Sun, 2008) and is the best instructional type in all situations when it comes to grammar. In fact, language production in output-oriented instructions which include teacher feedback and scaffolding (our study did not include them) may help learners even more in terms of grammar acquisition due to lowering cognitive burden on one hand and raising the chance of output modifications and language development on the other hand (Toth, 2006).

\section{Conclusions}

As pointed out by SLA researchers (Benati, 2017; Ellis, 1981; VanPatten, 2000, 2007), it is evident that input is necessary. Nevertheless, the way learners are exposed to it may be of a greater importance. More specifically, Benati (2016) asserts that there is a shift of focus in ELT (English Language Teaching) from the original question "does instruction make a difference?" to the more specific question "does manipulating input make a difference?" (p. 65). On the other hand, motivated by the efficacy of FonF approach to teaching grammatical structures, PI has attracted renewed interest in recent years. It has been argued that PI "would increase intake from the input and ultimately improve acquisition” (Husseinali, 2016, p. 115).

Moreover, the power of PI is not only due to its attention to language form but also the strategies in the process of PI by which learners can retain and thus use new grammatical structures during both L2 interpretation and production tasks. Accordingly, it may be the case that PI facilitates L2 grammar acquisition since it includes a combination of elements which is effective for L2 production as well as comprehension (Dekeyser \& Botana, 2014), especially for the learners in lower proficiency levels. Therefore, from the vantage point of PI components, SLA scholars should reinvigorate this research stream, especially in different contexts using various linguistic features so as to achieve a broader and deeper understanding of the polyvalent character of this type of L2 instruction. As Dekeyser and Botana (2014) stated, "PI research, if conducted carefully, can provide a better understanding of basic psycholinguistic questions about second language acquisition (the role of 
enhanced input, explicit learning processes, or different kinds of practice in skill development)" (p. 2).

The pedagogical implication of the study is that PI, as a FonF instruction, may contribute to drawing learners' attention to target forms while they engage in meaningful activities. The study also suggests that learners' early plunging in output practices may be of less benefit since they may not have received the appropriate intake to use it in the process of output practice. Having said that, both input and output-based instructions are advantageous and may be of greater value if they are employed properly as complementary methods in L2 classrooms (Shintani et al., 2013; Toth, 2006). The present study also suggests the view that DG as a form of consciousness-raising activity may have a greater instructional value if learners are proficient and that early demand on learners to reconstruct a text may not contribute to making the form-meaning connection. However, future studies can shed some lights on the issue.

Although the present study implies that PI is an effective instructional approach to FL learners in the Iranian context, as already discussed, there is a dispute whether PI can be considered as a FonF approach since "both explanation and practice occur outside of what are normally understood to be communicative activities, making the technique more a 'focus on formS' rather than a 'focus on form' one" (Sheen, 2007; p. 162). Additionally, 'drawing sweeping conclusions' about the role of PI is 'premature' since, as DeKeyser, Salaberry and Robinson (2002) argue, learning and processing a new structure depend on various factors such as "the transparency of the form meaning connection, the abstractness of the structure involved, the similarity with the native language, and the nature of the skill required" (p. 820), we should be cautious not to draw a hasty conclusion that PI as a FonF instruction alter the way the participants process a foreign language.

As the limitation of the study, it should be noted that the present study had no delayed posttest (because at the end of the semester the majority of participants were no longer available) to measure long-term effect of the treatments. Another limitation of the study was the fact that it was not possible to randomly assign the participants to three groups since they had already enrolled in the appropriate classes based on the institute's instructions and rules.

Last but not least, another limitation of the study lies in the fact that although the teacher had students work in groups, the meaningful output activities used in the present study were not communicative in nature. The reason for choosing such tasks was that there was an attempt to make all the instructional material the same and make sure that the differences in treatment were only because of the treatment themselves (not the different discourses). In fact, production-based practices can be more effective depending on the way they are implemented to foster meaning and communication among L2 learners (Dekeyser \& Botana, 2014; Shintani et al., 2013; Toth, 2006). 
Eventually, future studies with larger samples and delayed posttests would illuminate the systematic differences between grammar instruction types in a more specific and accurate manner. Moreover, the consideration of the prominent role of language functions along with the forms may give scholars new insights regarding both theoretical views and pedagogical implications of this field of study. This may encourage curriculum developers and teachers to design integrative and flexible grammar teaching methods so as to raise the effectiveness of EFL learners' learning process, especially regarding more complicated structures such as passive voice.

\section{References}

Alderson, C. (1997). Models of language: whose? what for? what use? In A. Ryan \& A. Wray (Eds.), Evolving models of language: British Studies in Applied Linguistics 12, (pp. 1-22). Clevedon: BAAL/Multilingual Matters.

Benati, A. (2005). The effects of processing instruction, traditional instruction and meaningoutput instruction on the acquisition of the English past simple tense. Language Teaching Research, 9(1), 67-93.

Benati, A. (2016). Input manipulation, enhancement and processing: Theoretical views and empirical research. SSLLT, 6(1), 65-88.

Benati, A. (2017). The role of input and output tasks in grammar instruction: Theoretical, empirical and pedagogical considerations. SSLLT, 7(3), 377-396.

Cadierno, T. (1995). Formal instruction from a processing perspective: An investigation into the Spanish past tense. Modern Language Journal, 19, 179-193.

DeKeyser, R. M. (1997). Beyond explicit rule learning; Automatizing second language morphosyntax. Studies in Second Language Acquisition, 19, 195-221.

DeKeyser, R. M. (2001). Automaticity and automatization. In P. Robinson (Ed.), Cognition and second language instruction (pp. 125-151). New York: Cambridge University Press.

DeKeyser, R., Salaberry, R., Robinson, P., \& Harrington M. (2002). What gets processed in processing instruction? A commentary on Bill VanPatten's processing instruction: an update. Language Learning, 52(4), 805-23.

Dekeyser, R., \& Botana, G. P. (2014). The effectiveness of processing instruction in L2 grammar acquisition: A narrative review. Applied Linguistics, 36(3), 290-305. doi:10.1093/applin/amu071

Doughty, C., \& Williams, J. (1998). Pedagogical choices in focus on form. In C. Doughty \& J. Williams (Eds.), Focus on form in classroom second language acquisition (pp. 197-262). New York: Cambridge University Press.

Ellis, R. (1981). The role of input in language acquisition: some implications for second language teaching. Applied Linguistics, 2, 70-82.

Ellis, R. (1994). The study of second language acquisition. Oxford, England: Oxford University Press.

Ellis, R., \& He, X. (1999). The roles of modified input and output in the incidental acquisition of word meanings. Studies in Second Language Acquisition, 21, 285-301.

Ellis, R. (2002). Does form-focused instruction affect the acquisition of implicit knowledge? A review of the research. Studies in Second Language Acquisition, 24, 223-236.

Ellis, R. (2003). Task-based language learning and Teaching. Oxford, England: Oxford University Press.

Ellis, R. (2016). Focus on form: A critical review. Language Teaching Research, 20, 405-428. 
Farley, A. P. (2001). Authentic processing instruction and the Spanish subjective. Hispania, 84, 289-299.

Farley, A. P. (2004). The relative effects of processing instruction and meaning-based output instruction. In B. VanPatten (Ed.), Processing instruction: Theory, research and commentary (pp. 143-168). Mahwah, NJ: Erlbaum.

Husseinali, G. (2016). Arabic L2 interlanguage: Syntactic sequences, agreement and variation. New York: Routledge.

Iwanaka, T. (2007). Roles of noticing in English language learning: A literature review. Languages \& Literatures, 2, 53-67.

Izumi, S. (2002). Output enhancement, and the noticing hypothesis: An experimental study on ESL relativization. Studies in Second Language Acquisition, 24, 541-577.

Lee, J., \& VanPatten, B. (1995): Making communicative language teaching happen. New York: McGraw-Hill.

Lew, W. M. A. (2008). Processing Instruction and Second Language Grammar Acquisition, APPLE Award Winning Papers in AL \& TESOL, 8 (2), 1-33.

Long, M. (1991). Focus on form: A design feature in language teaching methodology. In K. de Bot, R. Ginsberg \& C. Kramsch (Eds.), Foreign Language Research in Cross-cultural Perspective (pp.39-52). Amsterdam: John Benjamin.

Mackey, A. (1999). Input, interaction and second language development: An empirical study of question formation in ESL. Studies in Second Language Acquisition, 21, 557-587.

Norris, J., \& Ortega, L. (2000). Effectiveness of L2 instruction: A research synthesis and quantitative meta-analysis. Language Learning, 50, 417-528.

Qin, J. (2008). The effect of processing instruction and dictogloss tasks on acquisition of the English passive voice. Language Teaching Research, 12(1), 61-82.

Schmidt, R. (1990). The role of consciousness in second language learning. Applied Linguistics, $11,129-158$.

Shack. (2004). Children using dictogloss to focus on form. Reflections on English Language Teaching, 5(2), 47-62.

Sharwood-Smith, M. (1993). Input enhancement in instructed SLA: Theoretical bases. Studies in Second Language Acquisition, 15, 165-179.

Sheen, R. (2007). Processing instruction. ELT Journal, 61(2), 161-163.

Shintani, N., Li, Shaofeng, \& Ellis, R., (2013). Comprehension-based versus production-based grammar instruction: A meta-analysis of comparative studies. Language Learning, 63(2), $296-329$.

Swain, M. (1998). Focus on form through conscious reflection. In C. Doughty \& J. Williams (Eds.), Focus on form in classroom second language acquisition (pp. 64-81). New York: Cambridge University Press.

Swain, M. (2000). French immersion research in Canada: Recent contributions to SLA and applied linguistics. Annual Review of Applied Linguistics, 20, 199-212.

Sun, Y. A. (2008). Input processing in second language acquisition: A discussion of four input processing Models. Working Papers in TESOL \& Applied Linguistics, 8(1), pp.1-10.

Toth, P. D. (2006). Processing instruction and a role for output in second language acquisition. Language Learning, 56(2), 319-385.

Vahedi-Langroodi, M. M. (1996). The syntax, semantics and argument structure of complex predicates in modern Farsi. (Unpublished doctoral dissertation). University of Ottawa, Canada. http://dx.doi.org/10.20381/ruor-7974

VanPatten, B., \& Cadierno, T. (1993). Explicit instruction and input processing. Studies in Second Language Acquisition, 15, 225-43. 
VanPatten, B. (1996). Input processing and grammar instruction: They and research. Westport, CT: Ablex

VanPatten, B. (2000). Processing instruction as form-meaning connection: Issues in theory and research. In Lee, J. F. \& Valdman, A.,(Eds.), Form and meaning in language teaching(4368). Boston: Heinle\&Heinle.

VanPatten, B. (2004a). Input and output in establishing form-meaning connection. In B. VanPatten, J. Williams, S. Rott \&. M. Overstreet (Eds.), Form-meaning connection in second language acquisition (pp. 29-47). Mahwah, NJ: Erlbaum.

VanPatten, B. (2004b). Input processing in second language acquisition. In B. VanPatten (Ed.), Processing instruction: Theory, research, and commentary (pp. 5-32). Mahwah, NJ: Erlbaum.

VanPatten, B. (2005). Processing instruction. In C. Sanz (Ed.), Mind and context in adult second language acquisition (pp. 267-281). Washington, DC: Georgetown University Press.

VanPatten, B. (2007). Input processing in adult second language acquisition. In B. VanPatten \& J. Williams (Eds.), Theories in second language acquisition (pp. 115-135). Mahwah, NJ: Erlbaum.

VanPatten, B., Inclezan, D., Salazar, H., \& Farley, A. P. (2009). Processing Instruction and Dictogloss: A study on object pronouns and word order in Spanish. Foreign Language Annals, 42(3), 557-575.

Wajnryb, R. (1990). Grammar dictation. Oxford, UK: Oxford University Press.

Williams, J., \& Evans, J. (1998). What kind of focus and on which forms? In C. Doughty \& J. Williams (Eds.), Focus on form in classroom second language acquisition (pp. 139-155). New York: Cambridge University Press.

Wong, W. (2004). Processing instruction in French: The roles of explicit information and structured input. In B. VanPatten (Ed.), Processing instruction: Theory, research, and commentary (pp. 187-205). Mahwah, NJ: Erlbaum. 


\section{Appendix A. Samples of structured input activities in processing instruction materials}

I. Look at the following six drawings. Choose a sentence that matches the meaning of each drawing.
a) John invites Mary to a party.
b) John is invited by Mary to a party.
2 a) The boy chases the dog.
b) The boy is chased by the dog 3
a) The old woman fed the child.
b) The old woman was fed by the child
a) The bad boy beat Ralph
b) The bad boy was beaten by Ralph
5
a) The spider caught the big insect
b) The spider was caught by the insect
.6 a) He pinched the child
b) He was pinched by the child

\section{(Pictures provided on a separate sheet)}

II. The following is a story about a farmer and a snake. Choose a sentence that fits the meaning of each context. (Please refer to Dictogloss Task Passage 2 in Appendix B for the complete story.)

On a cold day in winter, a snake is very hungry.

1. The snake (go) out for food.

2. It is snowing. The snake (freeze) on a road.

3. The snake (pick up) by the farmer

4. At that time a farmer (pass) by.

5. The snake(find) by the farmer

6. The farmer (bite) by the snake.

7. The farmer (ask) the snake 'why did you hurt me?

8. The snake (leave) the farmer. a) goes

a) freezes

b) is gone

a) picks up

a) passes

a) finds

a) bites

a) asks

a) leaves b) is frozen

b) is picked up

b) is passed

b) is found

b) is bitten

b) is asked

b) is left

III. You will hear a story about a tiger and a rabbit. Then answer the following questions:

1. Who sees the ball?

2. Who pushes the ball?

3. The ball is stopped by what?

4. Who pulls the rabbit?

5 . Who killed the tiger?

6 . Who holds the rabbit? 
(Please refer to Dictogloss Task Passage 1 in Appendix B for the complete story.)

IV. Listen to the instructor making a series of statements. Check whether you have seen these things

before or not.

$$
\text { Yes No }
$$

1.

2 .

3.

4.

5 .

6.

7.

8

Instructor's script

1. A thief followed a policeman.

2. A cat was chased by a dog.

3. A car collided with a tree or a wall.

4. You were asked to stay in your bed because you were sick.

5. A student was taught by a classmate.

V.Listen to the instructor making a series of statements. Check whether you have experienced these

things before or not.

1.

2.

3.

4.

5.

6.

Instructor's script

1. You were invited by a friend to dinner.

2. You were helped by others.

3. You were bitten by an insect.

4. You were treated with an injection.

5. You were advised to study hard. 


\section{Appendix B. Dictogloss task passages}

\section{Dictogloss task passage 1}

One day a tiger is hungry. He goes out for food.............

the story of the tiger and rabbit was adapted from Qin (2008).

\section{Dictogloss task passage 2}

On a cold day in winter, a snake is very hungry....

The story of snake and farmer was adapted from Qin (2008).

\section{Appendix C. Meaningful output activities}

I. Look at the following eight drawings and complete the sentences.
1. a- John
b- Mary-
2. a- The boy
b- The dog
3. a. The old woman--------
b. The child
4. The bad boy
b. Ralph
5. The big insect
b. The spider
6. The child
b. $\mathrm{He}$

(Pictures provided on a separate sheet)

II. After reading the story about a farmer and a snake, fill in the blanks. You have 10 minutes time to read the story and return the paper to your teacher. (The following sentences were on a separate sheet).

1.The snake (go) out for food.

2. It is snowing. The snake(freeze) on a road.

3. The snake (pick up) by the farmer

4. At that time a farmer (pass) by.

5. The snake (find) by the farmer

6. The farmer (bite) by the snake.

7. The farmer (ask) the snake 'why did you hurt me?'

8. The snake (leave) the farmer.

III. You will hear a story about a tiger and a rabbit. Then complete the following sentences.

1. The ball hits a stone and the stone.

2. The ball by the rabbit.

3. The tiger by a gun.

4. The rabbit tries to pull the ball, but the ball

5. Then the ball and the rabbit

IV. Listen to the instructor making a series of statements. You may have experienced or heard about the following situations. You complete the second sentences using passive voices. 
1. If you speed up in the streets, you (given- a ticket- by - a policeman- are)

2. You are an old man and standing up on a crowded bus, (a seat- by- given - youare-a polite young man)

3. Your friend Reza and you are walking out of the language institute, you both feel hungry, (Invites- you- to a sandwich- Reza)

4. When the country was at war with the enemies, (were- killed-a lot of soldiers- bythe enemy planes)

5. You studied hard. You took the exam. (given- you-are-a good mark- the teacherby)

6. You were sick. You were taken to the hospital. (given-you-are-an injection)

\section{Appendix D. The test}

I. Underline the doer of the action of the following sentences. If you cannot find the doer put $\mathrm{N}$

(not mentioned) in front of the sentences.

1. Every day the milkman delivers milk to the neighbors.

2. All the students were taught English.

3 . The driver was stopped by a policeman on the street.

4. Sam bought Bob a present.

5 . We were told to open our books.

II. Underline the recipient of the action of the following sentences.

1. The dog saw Tom.

2. The workers are paid by the company.

3. It was invented 100 years ago.

4. Blueberries grow on trees.

5. Sue was invited to the party.

III. Choose the correct answer that responds to the following dialogues appropriately.

1.Who ate the apple?

A. The apple ate by Tom.

B. The apple was eaten by Tom.

$2 . \quad$ Who prepares the breakfast?

A. The breakfast is prepared by my mother.

B. The breakfast prepares by my mother.

3. Who repaired the watch?

A. The watch was repaired by Jim.

B. The watch repaired by Jim.

4. Who was taken to the park?

A. The father was taken by the little child.

B. The little child was taken by his father. 
IV. Choose a sentence that fits the contexts provided.

1. A cow is hungry and wants to eat an apple in the tree. Then the apple falls to the ground.

a) The cow hits the apple. b) The cow is hit by the apple.

2. A cat hurts a dog. The dog is mad. Then the cat says, 'That hurts!'

a) The cat is bitten by the dog b) The cat bites the dog.

3. There is an accident. One of the drivers is injured.

a) An ambulance is taken to the hospital by the injured man. b) The ambulance takes the injured man to the hospital.

V.Translate the following English sentences into Farsi.

1. A group of students is followed by a teacher.

2. Casey gave a gift to a teacher, but the gift was broken.

3. Ralph was ordered to leave the class.

4. The table was broken into pieces.

VI. Based on the contexts, fill in blanks with the verbs provided in an appropriate voice.

1. A monkey climbs up onto a tree and sees a bird's nest. The monkey wants to get the nest. The bird is mad. Then, the bird (bite) the monkey. And the monkey has to run away.

2. A cat steps on a dog's tail unintentionally. The dog feels pain and is mad. Then, the cat------ (kick) the dog. The cat says, 'That hurts!'

3. The thief breaks into the house. The policeman watches him. The thief (arrest) by the policeman.

4. The baby cries. Mother knows that she is hungry. The baby (feed) by her mother.

5. Lisa is happy. It is her birthday. She is given (give) a lot of presents.

VII. Fill in the blanks with the passive or active voice of the verb in parentheses. Use an appropriate tense.

A few weeks ago, while I was shopping at the supermarket near my house, (rob). I was at the checkout counter, paying my groceries. When I (2) _ (give) my change by the cashier, I (3) (put) it

in my purse. As I (4) (walk) out of the store, I (5)

(feel) a pull at my purse. Suddenly, I (6) (see) a man run past me. I ran back into the store and (7) ------------(tell) the manager what happened. The manager called the police immediately. When the police 
arrived, I told them "My wallet (8) (steal)". Actually, the thief got on the train and disappeared.

Pictures are related to appendix $\mathrm{A}$ and $\mathrm{C}$
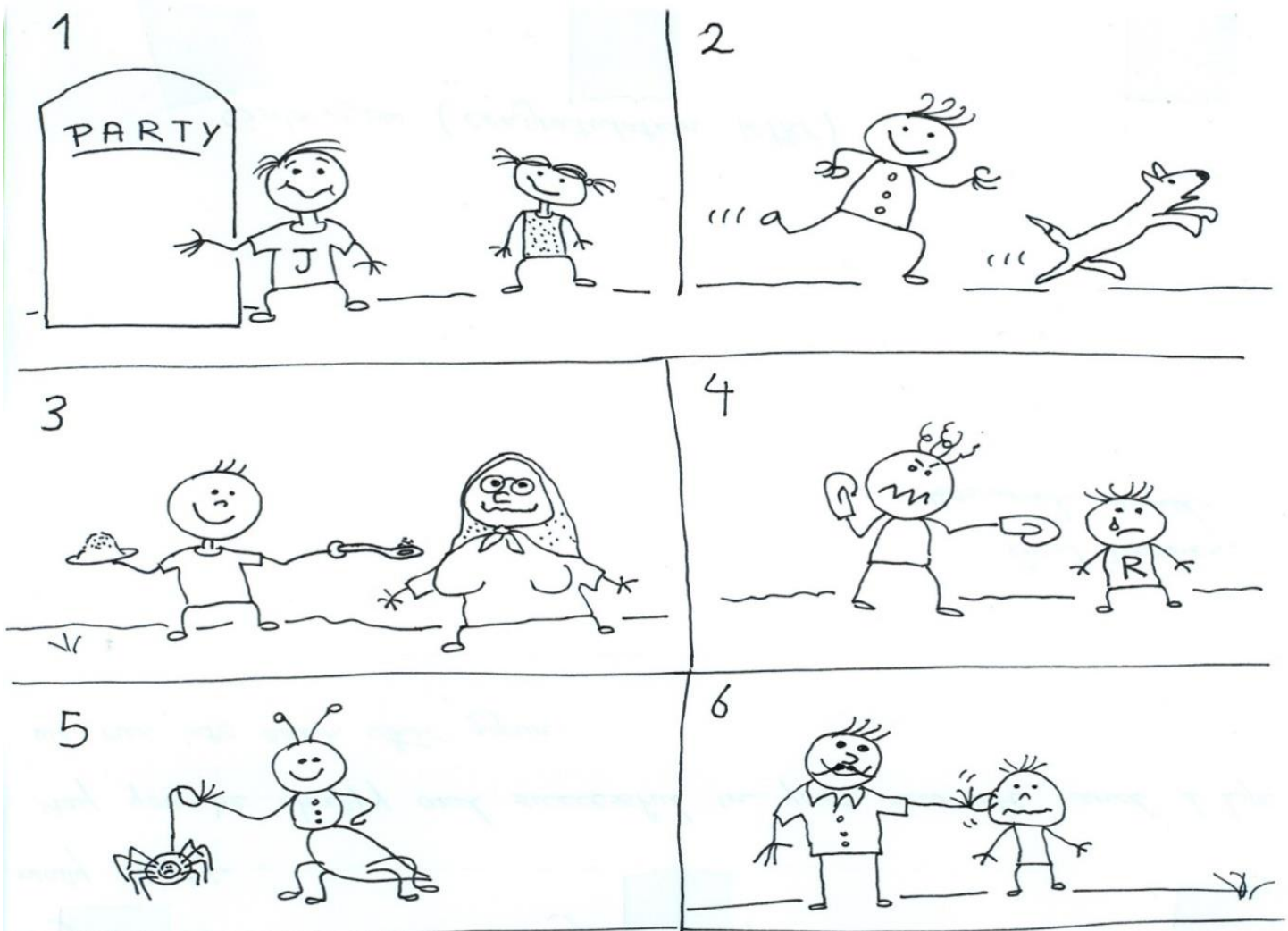

\section{Copyrights}

Copyright for this article is retained by the author(s), with first publication rights granted to the Journal. This is an open-access article distributed under the terms and conditions of the Creative Commons Attribution license (CC BY-NC-ND) (http://creativecommons.org/licenses/by-nc-nd/4.0/). 